\title{
Determinants of STI's and contraceptive awareness among Indian adolescents: a hospital based study
}

\author{
Nidhi Gupta, Neha Varun, Arifa Anwar, Aruna Nigam \\ Corresponding author: Dr. Nidhi Gupta, Address: A-2591, Second floor, Green fields colony, \\ Faridabad, Haryana. 121010, India; Email : drnidhigupta19@gmail.com
}

Distributed under Attribution-Non Commercial - Share Alike 4.0 International (CC BY-NC-SA 4.0)

\begin{abstract}
Objective: This study was done to assess the awareness of various contraceptive methods and sexually transmitted diseases among the adolescent females. Methods: It is a prospective observational study done in outpatient department of Obstetrics \& Gynecology Department of Hamdard Institute of Medical Sciences \& Research over a period of one year. All the unmarried and married adolescent females with age 11-19 years who came to the hospital with any complaints were asked about their awareness regarding various methods of contraception and sexually transmitted diseases with the help of a pre-designed questionnaire. Results: Among these 216 participants, $69 \%$ were unmarried and 30\% were married. Among unmarried, knowledge of contraception was present in $57.6 \%$ as compare to $72.3 \%$ among married participants. In our study, barrier method of contraception was the most acknowledged method followed by emergency contraceptive pills. Among all participants who were having knowledge of STI's (sexually transmitted infection), HIV is the only STI known. Conclusion: Safe sexual practices should be encouraged to avoid long term health and social disadvantages.
\end{abstract}

Keywords: Adolescent, contraception, sexually transmitted diseases, awareness.

Adolescent has been defined by World Health Organization (WHO) as the age group of 10-19 years. In India, adolescents represent over $1 / 5$ th of total population. This group of population is not homogeneous group but having a diversity in situations; their situation varies by age, sex, marital status, class, religion, family environment and cultural context. ${ }^{1}$

Adolescence phase is characterized by profound biological, psychological and social developmental changes that leads to sexual curiosity, risk taking behavior, mood swings, somatic or psycho social problems, substance abuse and vulnerable to various diseases at younger age. Sometimes this phase is passed gradually and smoothly but at times it can be explosive and turbulent. Adolescents are one of those underserved segments of the population, partly due to comparatively low morbidity and partly due to complexities of issues involved. The percentage of health visits in this sector is only 5 to $7 \% .^{2}$
According to the National AIDS Control Organization, the number of HIV cases less than 20 years of age is between 15 to $20 \%{ }^{2}$ Creating awareness about safe sexual practices, STIs, their modes of transmission, contraception in the adolescent age group is a best way to put a check on this situation. During this COVID pandemic where every country was facing lockdown as in India, contraception was a must thing to decrease the unwanted pregnancies. Therefore, an attempt was made to assess the level of awareness regarding contraception and STIs amongst the adolescents in the age group of 11-19 years and determinant which affect this awareness was studied.

Materials and methods

It is a prospective observational study was done in outpatient department (OPD) of obstetrics and gynecology of Hamdard Institute of Medical Sciences and Research over a period of one year from January 2018 to December 2018. All the unmarried and married adolescent females with age 11-

Received: $17^{\text {th }}$ July 2020, Peer review completed: $25^{\text {th }}$ August 2020, Accepted: $7^{\text {th }}$ September 2020.

Gupta N, Varun N, Anwar A, Nigam A. Determinants of STI's and contraceptive awareness among Indian adolescents: a hospital based study. The New Indian Journal of OBGYN. 2021; 8(1): 130-34. 
The New Indian Journal of OBGYN. 2021 (July-December);8(1)

19 years who came to the hospital with any complaints were asked about their awareness regarding various methods of contraception and sexually

transmitted diseases with the help of a pre- designed, pretested questionnaire. The girls with age $<11$ or $>19$ years and who were not willing to participate in the study were excluded from the study. Chi square test and standard statistical tests were used for data analysis. $\mathrm{P}$ value $<0.05$ was considered significant.

\section{Results}

During the study period, 320 adolescent females came to our OPD for various complaints. Out of 320, 216 were knowledge is significantly higher in married girls than unmarried girls. Contraceptive knowledge is significantly higher in students and housewives as compare to working girls which also include laborers. This may be due to the inclusion of sex education and reproductive biology in school curriculum. Rest determinants were not showing any significant results. The unmarried girls who were having knowledge of contraception were 87 and out of this, 15 girls were sexually active (table 2 ).

Among the modes of knowledge of contraception, television $(n=86,64.2 \%)$ and husband $(n=46,34.3 \%)$ were the most common source followed by internet $(n=25,18.6 \%)$

\begin{tabular}{|c|c|c|c|c|}
\hline $\begin{array}{l}\text { Parameters } \\
\text { observed }\end{array}$ & $\begin{array}{c}\text { Knowledge of } \\
\text { contraception } \\
\text { YES } \\
\text { No. }(\%) \\
\end{array}$ & $\begin{array}{c}\text { Knowledge of } \\
\text { contraception } \\
\text { NO } \\
\text { No. }(\%) \\
\end{array}$ & $\begin{array}{l}\text { Total } \\
\text { No. }(\%)\end{array}$ & $P$ value \\
\hline \multicolumn{5}{|l|}{ A) Marital Status } \\
\hline Unmarried & $87(57.6)$ & $64(42.4)$ & 151 & \multirow{2}{*}{$\begin{array}{l}0.04 \\
\text { (significant) }\end{array}$} \\
\hline Married & $47(72.3)$ & $18(27.7)$ & 65 & \\
\hline \multicolumn{5}{|l|}{ B) Age (years) } \\
\hline $11-13$ & $9(64.3)$ & $5(35.7)$ & $14(6.5)$ & \multirow{3}{*}{$\begin{array}{l}0.58 \text { (not } \\
\text { significant) }\end{array}$} \\
\hline $14-16$ & $34(68)$ & $16(32)$ & $50(23.1)$ & \\
\hline $17-19$ & $91(59.9)$ & $61(40.1)$ & $152(70.4)$ & \\
\hline \multicolumn{5}{|l|}{ C) Education } \\
\hline Illiterate & $3(50)$ & $3(50)$ & $6(2.8)$ & \multirow{4}{*}{$\begin{array}{l}0.42 \text { (not } \\
\text { significant) }\end{array}$} \\
\hline Primary/ Secondary & $75(67.6)$ & $36(32.4)$ & $111(51.4)$ & \\
\hline Higher Secondary & $45(56.9)$ & $34(43)$ & $79(36.6)$ & \\
\hline Graduate & $11(57.9)$ & $8(42.1)$ & $19(8.8)$ & \\
\hline \multicolumn{5}{|l|}{ D) Religion } \\
\hline Hindu & $88(59)$ & $61(40.9)$ & $149(68.9)$ & \multirow{3}{*}{$\begin{array}{l}0.5 \text { (not } \\
\text { significant) }\end{array}$} \\
\hline Muslim & $43(67.2)$ & $21(32.8)$ & $64(29.6)$ & \\
\hline Christian & $2(66.7)$ & $1(33.3)$ & $3(1.4)$ & \\
\hline \multicolumn{5}{|l|}{ E) Occupation } \\
\hline Student & $83(57.2)$ & $62(42.8)$ & $145(67.1)$ & \multirow{3}{*}{$\begin{array}{l}0.005 \\
\text { (significant) }\end{array}$} \\
\hline Housewife & $45(78.9)$ & $12(21.1)$ & $57(26.4)$ & \\
\hline Working & $6(42.9)$ & $8(57.1)$ & $14(6.5)$ & \\
\hline
\end{tabular}

willing to participate in the study. Amongst these 216 and books $(n=30,22.4 \%)$. Friends $(n=9,6.7 \%)$ and partner in participants, unmarried females were $151(69.9 \%)$ and rest of case of unmarried girls $(n=6,4.4 \%)$ contribute to lesser the females were married $(n=65,30.1 \%)$. Sexually active degree for the source of knowledge of contraception.

females among unmarried is 28 (9.9\%) making the prevalence of sexual activity $16.9 \%$ in this study. Various determinants like marital status, education level, age, religion, occupation assessing the knowledge of contraception were studied and shown in table 1.

Among the methods of contraception known to participants, barrier was known to all participants $(n=134$, $100 \%)$ followed by emergency I pill $(n=47,35 \%)$, oral contraceptive pills $(n=38,28.3 \%)$, intrauterine contraceptive device $(n=9,6.7 \%)$ and injectables $(n=7,5.2 \%)$.

\begin{tabular}{llll} 
Table 2: Usage of contraception & & & \\
\hline Usage & $\begin{array}{l}\text { Unmarried sexually active } \\
(\mathbf{n}=\mathbf{1 5}) \text {; Number (\%) }\end{array}$ & $\begin{array}{l}\text { Married (n=47) } \\
\text { Number (\%) }\end{array}$ & $\begin{array}{l}\text { P value } 0.12 \text { (not } \\
\text { significant) }\end{array}$ \\
\hline Yes & $9(60)$ & $25(53.2)$ & $22(46.8)$ \\
No & $6(40)$ & $\begin{array}{l}\text { Unmarried sexually active with } \\
\text { knowledge of contraception (n=9) }\end{array}$ & $\begin{array}{l}\text { Married with knowledge of } \\
\text { contraception (n=25) }\end{array}$ \\
\hline Method of contraception & $5(55.5)$ & $15(60)$ & P value 0.95 (not \\
& $3(33.3)$ & $7(28)$ & significant) \\
\hline Barrier & $1(11.1)$ & $3(12)$ & \\
Emergency pills & & \\
Both
\end{tabular}

The knowledge of contraception in our study was present in $134(62 \%)$ girls. The table shows that the contraceptive
Table 2 shows the data on usage of various contraceptive methods in both the groups. The difference in both the 
groups was not statistically significant. Out of 28 unmarried sexually active females, 15 were having knowledge of any contraceptive method so usage of contraception was calculated from these 15 girls.

\begin{tabular}{|c|c|c|c|c|}
\hline $\begin{array}{l}\text { Parameters } \\
\text { observed }\end{array}$ & $\begin{array}{c}\text { Knowledge of } \\
\text { STI's } \\
\text { YES } \\
\text { No. }(\%)\end{array}$ & $\begin{array}{c}\text { Knowledge of } \\
\text { STI's } \\
\text { NO } \\
\text { No. }(\%)\end{array}$ & $\begin{array}{l}\text { Total } \\
\text { No. }(\%)\end{array}$ & $P$ value \\
\hline $\begin{array}{l}\text { A) Marital Status } \\
\text { Unmarried } \\
\text { Married }\end{array}$ & $\begin{array}{l}58(38.4) \\
30(46.1) \\
\end{array}$ & $\begin{array}{l}93(61.6) \\
35(53.8) \\
\end{array}$ & $\begin{array}{l}151(69.9) \\
65(30.1) \\
\end{array}$ & $\begin{array}{l}0.28 \text { (not } \\
\text { significant) }\end{array}$ \\
\hline $\begin{array}{l}\text { B) Age (years) } \\
11-13 \\
14-16 \\
17-19 \\
\end{array}$ & $\begin{array}{l}4(28.6) \\
21(42) \\
63(41.4) \\
\end{array}$ & $\begin{array}{l}10(71.4) \\
29(58) \\
89(58.6) \\
\end{array}$ & $\begin{array}{l}14(6.5) \\
50(23.1) \\
152(70.4)\end{array}$ & $\begin{array}{l}0.63 \text { (not } \\
\text { significant) }\end{array}$ \\
\hline $\begin{array}{l}\text { C) Education } \\
\text { Illiterate } \\
\text { Primary/ Secondary } \\
\text { Higher Secondary } \\
\text { Graduate }\end{array}$ & $\begin{array}{l}3(50) \\
53(47.7) \\
25(31.6) \\
7(36.8)\end{array}$ & $\begin{array}{l}3(50) \\
58(52.3) \\
54(68.3) \\
12(63.2)\end{array}$ & $\begin{array}{l}6(2.8) \\
111(51.4) \\
79(36.6) \\
19(8.8)\end{array}$ & $\begin{array}{l}0.15 \text { (not } \\
\text { significant) }\end{array}$ \\
\hline $\begin{array}{l}\text { D) Religion } \\
\text { Hindu } \\
\text { Muslim } \\
\text { Christian }\end{array}$ & $\begin{array}{l}56(37.6) \\
30(46.9) \\
2(66.7) \\
\end{array}$ & $\begin{array}{l}93(62.4) \\
34(53.1) \\
1(33.3)\end{array}$ & $\begin{array}{l}149(68.9) \\
64(29.6) \\
3(1.4)\end{array}$ & $\begin{array}{l}0.29 \text { (not } \\
\text { significant) }\end{array}$ \\
\hline $\begin{array}{l}\text { E) Occupation } \\
\text { Student } \\
\text { Housewife } \\
\text { Working }\end{array}$ & $\begin{array}{l}53(36.6) \\
29(50.9) \\
6(42.9)\end{array}$ & $\begin{array}{l}92(63.4) \\
28(49.1) \\
8(57.1)\end{array}$ & $\begin{array}{l}145(67.1) \\
57(26.4) \\
14(6.5)\end{array}$ & $\begin{array}{l}0.17 \text { (not } \\
\text { significant) }\end{array}$ \\
\hline
\end{tabular}

students and housewives as compare to working girls which also include laborers. Television $(\mathrm{n}=86,64.2 \%)$ and husband $(n=46,34.3 \%)$ were the most common source of knowledge followed by net $(n=25,18.6 \%)$ and books $(n=30,22.4 \%)$. Friends $(n=9,6.7 \%)$ and partner in case of unmarried girls $(n=6,4.4 \%)$ contribute to lesser degree for the source of knowledge of contraception. This may be due to adolescent girls of this age may be feeling shy or hesitant to discuss these things among friends or family. Among the methods of contraception known to participants, barrier was known to all participants $(n=134, \quad 100 \%) \quad$ followed by emergency I pill $(n=47,35 \%)$, oral contraceptive pills $(\mathrm{n}=38,28.3 \%)$, intrauterine contraceptive device $(\mathrm{n}=$ $9,6.7 \%)$ and injectables $(\mathrm{n}=7,5.2 \%)$.

Renjhen et al done a study on college students which showed that $98 \%(153 / 156)$ of the students had

Awareness regarding STIs was present in $88(40.7 \%)$ of adolescent girls including both married and unmarried. STI knowledge was high in unmarried as compare to married females but this difference is not statistically significant. HIV was the only STI known to married as well as unmarried in our study.

To summarize, in our study prevalence of sexual activity was $16.9 \%$ among unmarried. The minimum age of marriage was 17 years. Knowledge of any contraceptive method is significantly lower in unmarried females. Barrier was the most common method acknowledged as well used among both unmarried and married females. HIV was the only STI being known in our study.

\section{Discussion}

In India, adolescent pregnancy presents a serious social and public health problem. Early childbearing is often associated with a young woman's failure to complete her education and expose them to various type sexually transmitted diseases. ${ }^{3}$ Sexually transmitted illnesses are mainly transmitted by sexual contact and are caused by a wide range of bacterial, viral, protozoa, fungal agents, and ectoparasites. $^{4}$

Contraception: In our study, we observed that the knowledge of contraception was present in 134/216 (62\%) girls. Contraceptive knowledge is significantly higher in knowledge about family planning methods and $86 \%$ $(134 / 156)$ of them had heard about contraceptives. ${ }^{5}$ Information about family planning and contraception in $73 \%$ $(115 / 156)$ study subjects was from the media, 33\% from newspapers, $32 \%$ from friends and $21 \%$ from health personnel. ${ }^{5}$

Aggarwal $\mathrm{O}$ et al ${ }^{6}$ done a study on 500 undergraduate students of the medical colleges of Delhi and reported the knowledge regarding, contraception to be $83.5 \%$, which was comparable to the study conducted in Ludhiana by Benjamin et al ${ }^{7}$ among 527 senior secondary school children, where $87 \%$ were aware of contraception.

Shah et al done a study on 500 adolescent girls between the ages of 15 to 19 years old and mostly 150 (30\%) were from collage commerce stream while the rest were from arts stream (13.6\%), science stream (22.2\%), high school $(20.26 \%)$ and other $(14.00 \%)$ were from rural area of Bhavnagar not attending any school or college and were at home and having formal education. Out of all only one participant was married and all other were unmarried. ${ }^{3}$

Idonije et al in 2011 done a study on Nigerian students which include 690 male and 814 female students. They found that the $492(60 \%)$ female participants had good knowledge about contraception. About 122 (15\%) of the female students had no knowledge of contraception whereas 
$134(16.46 \%)$ female students have knowledge about contraception but with wrong definition. 66(8.1\%) female students didn't give any response. The commonest source of information to the female students is friends $(27.1 \%)$, followed by books and Magazines (18.5\%), teachers (13.7\%) and parents/neighbors $(9.2 / 8.6 \%){ }^{8}$

Thaker et al done a study in randomly selected four schools (two private and two government schools) of Ahmedabad, India which included a total of 530 apparently healthy students aged between 14 and 16 years. They found in their study that 241 out of 265 students in private schools have some kind of right knowledge of contraception as compared to 192 out of 265 government school students. For private school students, friends $(39.4 \%)$ were the most prevalent source followed by parents $(27.38 \%)$, the Internet (20.74\%), and teachers $(8.29 \%)$. For government school students, friends $(46.35 \%)$ being the most common and parents $(29.68 \%)$ were the second most frequent source, rest being less frequent. ${ }^{9}$

STIs: In our study, awareness regarding sexually transmitted diseases was present in $88(40.7 \%)$ girls. Various determinants like marital status, age, religion, education, occupation was studied but no significant difference in either of the parameters in terms of knowledge of STIs was observed.

Baruah et al (2016) done a study on both sexes adolescent and they found that the awareness regarding STI was almost equally distributed throughout both age groups, $74.7 \%$ of adolescents had knowledge about STIs. This is higher than what we found in our study. Awareness was found to be high $(84.6 \%)$ among students, followed by the unemployed adolescent group (57.1\%). Awareness pattern was found significant $(\mathrm{P}<0.001)$, with respect to occupation of the adolescent. ${ }^{1}$ They have seen that the television has universally been found as the most effective source of information about STIS for the adolescents. However, the role of parents and relatives is alarmingly inadequate which may be an indirect reflection of their own ignorance and inhibitions regarding STIs. ${ }^{1}$

Rai et al (2011) done a study on urban slums and Aggarwal et al (2008) on health care providers, both the studies reported similar awareness regarding STIs that is $51.2 \%$. ${ }^{10,11}$ There was another study on urban slums of Mumbai, done by Raut et al and they found reasonably high level of awareness about STIs in these people (about $68.7 \%){ }^{12}$
Muthuraja et al had done a study on adolescent students of various schools and colleges in Chennai to find the awareness regarding HIV/AIDS. They have found that the awareness about general aspect of HIV/AIDS in their study was only $64 \%$ with girls being more aware than boys. Most of the females in this study knew about the transmission of HIV/AIDS from infected pregnant woman to child (59\%) compared to the males. Age wise comparison among the study group revealed that the late adolescent age group (64\%) was better informed about the spread of AIDS ${ }^{2}$.

Nanjunda in 2013 found in their study STI is more prevalent among the age group of $25-28$ years (50.6\%), male $(62.6 \%)$, illiterates $(42.2 \%)$, professional truck drivers $(38.6 \%)$, low income group (64\%) and unmarried adolescent people $(56 \%){ }^{13}$

Malleshappa et al done an intervention study and the study population included 656 girl students from 3 intermediate colleges (class XI \& XII) and 3 high schools (class X) of Kuppammandal in Chittoor district, Andhra Pradesh. They did a pre-test on study population to asses knowledge regarding menstruation, pregnancy, contraception as well as sexually transmitted diseases. Then they intervene with the help of health education programmes in multiple sessions and after this did a post-test to evaluate the difference. A significant increase in overall knowledge regarding menstrual cycle, ovulation, fertilization \& pregnancy by $44.5 \%$ was noted $(95 \% \quad \mathrm{CI}=42.5,46.5$; $\mathrm{P}<0.001)$. A significant improvement in the knowledge about transmission and prevention of STIs was noted after intervention $(\mathrm{P}<0.0001)$. They also found that the knowledge regarding individual methods of contraception increases significantly in post-test (oral contraceptive pills; 34.7 to $97.4 \%$, condom; 28 to $93.4 \%$, IUCD; 14.6 to $99.1 \%$, tubectomy; 15.5 to $89.4 \%)$. ${ }^{14}$

\section{Conclusion}

Safe sexual practices should be encouraged to avoid long term health and social disadvantages. Individual physical as well as social and societal factors influence adolescent sexual behavior. There is an urgent need to implement cultural sensitive and community based sexual and reproductive health education programs focusing rural people, especially adolescents. Such educational intervention programs must be given due importance, which will help the adolescent girls to take care of their own health and protect themselves from the risk of STIs and unwanted pregnancy.

Conflict of interest: None. Disclaimer: Nil. 
The New Indian Journal of OBGYN. 2021 (July-December);8(1)

\section{References}

1. Baruah A, Das BR, Sarkar AH. Awareness about sexually transmitted diseases among adolescents in urban slums of Jorhat district. Int J Med Sci Public Health. 2016; 5: 2373-7.

2. Muthuraja M, Dhanes V. Assessment of knowledge among adolescents regarding HIV/AIDS in Chennai, Southern India. Int J Contemp Pediatr. 2015 Nov; 2(4): 263-7.

3. Shah CJ, Solanki V, Mehta HB. Attitudes of Adolescent Girls Towards Contraceptive Methods. AMJ. 2011; 4(1): 43- 8 .

4. World Health Organization. Media Centre, Sexually Transmitted Infections. Zeneva: WHO; 2013. Available at: http://www.who.int/mediacentre/ factsheets/fs110/en/

5. Renjhen P, Kumar A, Pattanshetty S, Sagir A, Samarasinghe CM. A study on knowledge, attitude and practice of contraception among college students in Sikkim, India. J Turkish-German Gynecol Assoc. 2010; 11: 78-81.

6. Aggarwal O, Sharma AK, Chhabra P. Study in sexuality of medical college students in India. J Adolesc Health. 2000; 26: 226-9.

7. Benjamin AI, Panda P, Singh S, Bhatia AS. Knowledge \& Attitude of Senior Secondary School Students of Ludhiana Regarding Population Control \& Contraception. Indian Journal of Community Medicine. 2001; 26 (4):10-12.

8. Idonije BO, Oluba OM, Otamere HO. A Study on Knowledge, Attitude and Practice of Contraception Among Secondary School Students In Ekpoma, Nigeria. JPCS. 2011; 2: 22-7.

9. Thaker RB, Patel JR, Desai RM, Parmar JJ. Knowledge and practice regarding contraception and population control among higher secondary school students in
Ahmedabad. Int J Med Sci Public Health. 2015; 4: 77-80

10. Rai T, Aggarwal P, Kandpa SD. Knowledge, attitude, practice among adolescents regarding STI in urban slums. Indian J Community Health. 2011; 23(1): 26-8.

11. Aggarwal P, Kandpal SD, Gupta P, Negi KS. A KAP study regarding STI among Health Service Providers, Distt Dehradun. Indian J Prev Soc Med. 2008; 39(1\&2): 36-8.

12. Raut AV, Pakhare A. Youth and sexual health: A crosssectional study from an urban slum of Mumbai. Int $\mathbf{J}$ Med Sci Public Health. 2016; 5:138-41.

13. Nanjunda. Perceptions and knowledge of sexually transmitted diseases among rural people in India: Some ground realties. South East Asia Journal of Public Health. 2013; 3(2):47-51.

14. Malleshappa K, Krishna S, Nandini C. Knowledge and attitude about reproductive health among rural adolescent girls in Kuppammandal: An intervention study. Biomedical Research. 2011; 22 (3): 305-10.

\section{Nidhi Gupta ${ }^{1}$, Neha Varun ${ }^{2}$, Arifa Anwar ${ }^{3}$, Aruna Nigam ${ }^{4}$}

${ }^{1}$ Assistant professor, Department of Obstetrics \& Gynecology, Hamdard Institute of Medical Science and Research, New Delhi; ${ }^{2}$ Assistant professor, Department of Obstetrics \& Gynecology, All India Institute of Medical Science \& Research, New Delhi;

${ }^{3}$ Associate Professor, Department of Obstetrics \& Gynecology, Hamdard Institute of Medical Science and Research, New Delhi; ${ }^{4}$ Professor and unit head, Department of Obstetrics \& Gynecology, Hamdard Institute of Medical Science and Research, New Delhi. 